\title{
„S TURem tu i zítra budem": evaluace programu Ekocentra Podhoubí
}

\author{
Jan Činčera, Adéla Fleková, Jan Kopecký
}

Envigogika 2011/VI/3- Recenzované články/ Reviewed Papers

Publikováno/Published 31. 12. 2011

DOI: http://dx.doi.org/10.14712/18023061.62

\begin{abstract}
Abstrakt:
Článek prezentuje výsledky evaluačního výzkumu ročního programu Ekocentra Podhoubí určeného pro děti ve věku 8-11 let. Evaluace využívá smíšený design vycházející ze srovnání pretestu/posttestu experimentální/kontrolní skupiny, analýzy ohniskových skupin a nestrukturovaného pozorování. Podle výsledků výzkumu program účinně rozvíjí vybrané akční kompetence žáků a současně přesvědčení o jejich zvládnutí. Děti program interpretují jako zábavný a současně poučný a uvádí príklady jeho dopadu na vlastní znalosti, postoje a chování.
\end{abstract}

\section{Klíčová slova:}

Evaluace, smíšený design, kvaziexperiment, ohnisková skupina, integrovaná tematická výuka

\section{Abstract:}

This article presents results of evaluation research of one year-long programme for 8-11 years old pupils provided by the Ecocenter Podhoubi. Evaluation applied a mixeddesign based on experimental/control pre-test/post-test comparison, analysis of focus groups and non-structured observation. According to the research, the programme well develops selected pupils' action competencies and in the same time increases belief in their self-efficacy in dealing with them. Pupils interpret the program as both enjoying and meaningful and give examples of its impact on their own knowledge, attitudes and behaviour.

\section{Key words:} approach

Evaluation, mixed design, quasi-experimentation, focus group, integrated thematic 


\section{Úvod}

V České republice jsou nabízeny stovky původních programů environmentální výchovy. V nabídce ale jednoznačně dominuji krátké programy. Např́klad podle výroční zprávy Sdružení středisek ekologické výchovy Pavučina za rok 2009 realizovala její členská střediska celkem 9521 jednodenních a 363 pobytových programů (Daňková et al., 2010). Krátké výukové programy tedy $v$ nabídce téměř třicetkrát převyšují pobytové programy a představují tak nejtypičtější část nabídky.

Podle metaevaluačních studií je ale délka programu jedním z předpokladů jeho efektivity. Podle Zelezny (1999) je hranicí, od které se začne projevovat větší dopad programu, zhruba deset hodin. Obdobně podle Rickinsona (2001) fungují zpravidla vícedenní programy lépe než jednodenní. Př́iprava a realizace rozsáhlejších programů ale představuje nemalé úsilí. Realizátor musí takový program nejprve důkladně propracovat a ověřit. Přestože záleží na typu použité metodiky, mưže vývoj dobře fungujícího programu trvat i několik let. ${ }^{1}$

Rozsáhlejší programy zpravidla odpovídají jednomu ze dvou typů. Prvním jsou projekty, tj. programy, ve kterých žáci řeší určitý problém, podílejí se na vymezení cílů i plánu své práce a pracují v maximální možné míre samostatně.

Druhým typem programů je tzv. integrovaná tematická výuka. Ta je zpravidla organizována kolem určitého hlavního tématu či myšlenky, která je dále rozpracována do dílčích podtémat. $V$ průběhu takto organizovaného programu je to především učitel, kdo plánuje další postup, zpravidla podle předem připraveného schématu. Součástí integrovaných tematických celků ale mohou být i dílčí projekty (Horká et al., 2009; Kovalik \& Olsen, 1994).

Podmínkou realizace je ale také zájem ze strany klientů, tedy nejčastěji škol. Program musí být připravený tak, aby bylo pro školu atraktivní se do něj zapojit na celou dobu jeho trvání. U projektů se zpravidla využívá autentického zájmu dětí o řešení problémů $z$ jejich okolí. Taková strategie pracuje $s$ vnitřní motivací dětí, která je jedním z předpokladů jejich ochoty k proenvironmentálnímu chování (Darner, 2009).

Protože průběh integrované tematické výuky zpravidla určuje pedagog, hrozí, že děti o nabízené aktivity ztratí zájem. Programy proto často používají speciální typ prostředků pro motivaci dětí k zapojení. Takovým motivačním prostředkem múže být tzv. symbolický rámec, typický pro skautskou výchovnou metodu (Hořavová \& Klápště, 2006), zaháčkování (hooker) použivané v rámci programů výchovy o Zemi (Matre, 1999) či jiné prostředky.

Například program Strážci Země (Earthkeepers) ${ }^{2}$ uplatňuje širokou škálu motivačních prostředků. Děti jsou nejprve "zaháčkovány" dopisem, ve kterém je tajemný E.M. zve na návštěvu svého střediska. Celým programem pak prochází atmosféra tajemství, které děti postupně odhalují a (doslova) získávají klíče k jeho odemknutí (Matre \& Johnson, 1998). Jihoafrický program Water Wise věnovaný ochraně vody využívá jako motivační prostředky písničku zachycující hlavní tematické části programu, maskota Manziho, symbol dlaně, kde každý prst reprezentuje jedno téma, ale i doprovodné hry či klub pro děti (Rand Water, 2011).

1 Například programy výchovy o Zemi se zpravidla vyvíjí nejméně deset let, přičemž jejich vývoj pokračuje i po publikování.

2 Českou verzi programu připravuje ke spuštění na jaře 2012 Středisko ekologické výchovy Český ráj. 
Nabízí se otázka, do jaké míry se úsilí věnované takto propracovaným programům skutečně vyplatí. Výsledky většího počtu evaluací programů výchovy o Zemi shrnuje Martin (2003). Podle něj doložila většina prezentovaných výzkumů efekt programů na znalosti, postoje či chování dětí. V českém prostředí se evaluací integrovaných tematických celků v environmentální výchově zabývala Hornová (2007) a Činčera \&Macháčková (2009). Experimentální program HRSTi realizovaný a vyhodnocovaný Hornovou (2007) neprokázal efekt na sledované proměnné, z části patrně kvůli problémům s metodikou výzkumu. Program Expedice 4P realizovaný Podblanickým ekocentrem ČSOP Vlašim naopak opakovaně prokázal vliv na znalosti i postoje žákư (Činčera \& Macháčková, 2009).

Př́kladem propracovaného programu založeného na integrované tematické výuce je i program "S TURem tu i zítra budem" Ekocentra Podhoubí. V průběhu školního roku 2010/11 procházel program evaluačním výzkumem realizovaným ve spolupráci s Technickou univerzitou v Liberci. Cílem článku je prezentovat jeho metodiku a výsledky.

\section{Program}

Program "S TURem tu i zítra budem" je určen pro třetí až páté třídy základních škol. Trvá celý školní rok, od září do června.

Realizátoři předpokládají, že díky programu získají žáci znalosti a dovednosti související s každým tématem programu, nejméně jednu proenvironmentální činnost promítnou do běžného života školy a do svého mimoškolního chování, naučí se analyzovat environmentální problémy ve své obci, zlepší svoji schopnost spolupráce, diskuse i práce na počítači (interní dokumenty Ekocentra Podhoubí).

K dosažení těchto cílů děti prochází programem, který je organizačně rozčleněn do jednotlivých témat. Každé téma probíhá měsíc. V jeho průběhu žáci dostávají úkoly, které průběžně plní. Program se zabývá problematikou krajinného rázu, zdravé stravy, dopravy, úspor energie, odpadů, původu potravin, vodou, nebezpečnými materiály a problémy obce. Přestože program je řízen především učiteli pomocí zasílaných pracovních listů, obsahuje i tři celodenní akce řízené přímo lektory z Ekocentra Podhoubí.

Program má rozpracovaný motivační rámec. V něm děti vstupují do fiktivní země Turo. Země Turo má mapu, do které děti umist́ují nové stavby a snaží se o její trvale udržitelný rozvoj. Země je obývána tury, kterým děti pomáhají a jejichž dobrodružství, tematicky provázaná s programem, si každý měsíc čtou v komiksu. Mapa existuje i v digitální podobě na internetu, kde spolu mohou děti z rưzných "Tuřích" komunit navzájem komunikovat.

\section{Metodika evaluace}

Cílem evaluace bylo odpovědět na následující otázky:

Jak hodnotí program samotní účastníci? Jaké aktivity se jim líbily či nelíbily? Jaký význam přikládají motivačnímu rámci programu? Jak sami hodnotí vliv programu na rozvoj vlastních znalostí, postojů a chování?

Do jaké míry program ovlivnil vybrané proměnné, související s proenvironmentálním chováním? Jaký byl jeho vliv na přesvědčení dětí o zvládnutí určitých typů proenvironmentálního chování? Jaký byl jeho vliv na schopnost rozpoznat environmentálně odpovědné, resp. neodpovědné chování?

Základní zkoumanou množinou byli žáci třetích, čtvrtých a pátých tříd všech základních škol zapojených do programu (ve vzorku byla zastoupena jedna třetí třída, dvě čtvrté a pět pátých tříd). Ve sledovaném období, tj. školním roce 2010/11, probíhal 
program v celkem 12 třídách. Z nich se do výzkumu zapojilo celkem 8 tříd. Všechny třídy byly ze Středočeského kraje (program je nabízen školám pouze v tomto kraji). Po spárování bylo celkem získáno 134 spárovaných dotazníků od experimentální skupiny a 96 od kontrolní skupiny.

Tabulka 1. Experimentální skupina

\section{Experimentální skupina}

\begin{tabular}{|l|l|l|l|l|l|}
\hline Počet tříd & Žáků celkem & Z toho dívek & Neoznačeno & Z toho chlapců & Věkový průměr \\
\hline 8 & 134 & 67 & 5 & 62 & 10,46 \\
\hline
\end{tabular}

Kontrolní skupina byla sestavena metodou párování, tj. byla volena tak, aby byla co nejpodobnější té experimentální. Pokud to bylo možné, byla volena paralelní třída, nebo stejný ročník ze stejné školy. Byl osloven stejný počet tříd, jako prošel programem, shromáždit data se nakonec podařilo ze sedmi tř́d.

\section{Tabulka 2. Kontrolní skupina}

\section{Kontrolní skupina}

\begin{tabular}{|l|l|l|l|l|l|}
\hline Počet tříd & Žáků celkem & Z toho dívek & Neoznačeno & Z toho chlapců & $\begin{array}{l}\text { Věkový } \\
\text { prưměr }\end{array}$ \\
\hline 7 & 96 & 47 & 3 & 46 & 10,63 \\
\hline
\end{tabular}

Pro evaluaci byl zvolen smíšený design. Ten zahrnoval ohniskové rozhovory s experimentální skupinou, nezúčastněné pozorování experimentální skupiny a testy ve formě pretest - posttest, experimentální a kontrolní skupina.

Pro sběr kvalitativních dat byly použity dvě metody: nestrukturované pozorování a ohniskové skupiny vedené pomocí polostrukturovaných rozhovorů. Při formulaci otevřených otázek vycházeli tazatelé z předem připraveného seznamu, který podle situace modifikovali (Hendl, 2008, s. 173; Patton, 2006). Ohnisková skupina se skládala vždy $z$ pěti až osmi žáků. $V$ rámci evaluace proběhlo osm ohniskových skupin s celkem padesáti pěti žáky.

Pro sestavení skupin byla využita metoda sněhové koule. Nejprve byli do každé skupiny náhodně vybráni dva žáci z těch, kteří projevili ochotu podílet se na výzkumu. Ti si pak k sobě vybrali několik dalších spolužáků. Cílem bylo sestavit takové skupiny, ve které se budou respondenti cítit př́ijemně a nebudou mít před sebou zábrany.

Tazatelé pokládali postupně otázky a respondenti měli možnost se volně vyjádřit. Po několika provedených rozhovorech, když se otázky zdály nasycené, změnili tazatelé některé otázky (Švaříček \& Šed'ová, 2007, s. 88).

Tabulka 3. Experimentální skupina - rozhovory

\begin{tabular}{|l|l|l|l|l|l|}
\hline \multicolumn{2}{|l|}{ Experimentální skupina - rozhovory } \\
\hline Počet tříd & Žáků celkem & Z toho dívek & Věkový průměr & Z toho chlapců & $\begin{array}{l}\text { Věkový } \\
\text { průměr }\end{array}$ \\
\hline 8 & 55 & 28 & 10,14 & 27 & 10,46 \\
\hline
\end{tabular}


Nestrukturované pozorování bylo použito ve všech osmi třídách, které byly pozorovány ve dvou různých fázích programu. Cílem pozorování bylo sledování přijetí programu žáky a jejich spokojenost. Data z pozorování sloužila jako podpora nebo doplnění výsledků z rozhovorů (Hendl, 2008, s. 200). Pozorovatelé také sledovali, jak je ve třídě využíván motivační rámec, hodnocení a zapojení dětí do programu.

K zodpovězení evaluačních otázek evaluátoři navrhli dotazník, který částečně využil již existující nástroj na měření proenvironmentálních postojů. Tím byl standardizovaný dotazník proenvironmentálních postojů a chování CATES (Musser \& Malkus, 1994).

V CATES jsou položky formulovány z pohledu dvou různě smýšlejících dětí a a žáci mají vyplnit, jakému se více podobají. Test se hodnotí na škále od jedné do čtyř bodů (čtyři je nejvíce proenvironmentální chování). Žáci zaškrtávají menší či větší čtvereček, podle toho, jak moc se zvolenému dítěti podobají.

Použitý dotazník se skládal z několika částí:

1. Identifikační část, určovala pohlaví a věk respondenta.

2. Přesvědčení o zvládnutí proenvironmentálního chování (vycházející z CATES testu).

3. Identifikace environmentálně neodpovědného chování a jeho nahrazení, měřící akční kompetence.

Před zahájením výzkumu byl dotazník ověřen na jedné pilotní skupině pro vyhodnocení jeho interní reliability (Cronbach alfa test). Cronbachovo alfa zde nabývá hodnoty $v$ rozmezí jedna až nula, přičemž hodnota 0,7 a více znamená vysokou konzistenci a reliabilitu. Test Přesvědčení o zvládnutí proenvironmentálního chování měl hodnotu Cronbach alfa $=0,75$, a je tedy možné jej považovat za dostatečně reliabilní (Hendl, 2004, s. 50).

Sběr dat probíhal při programech v průběhu školního roku 2010/2011, v pololetí a na konci roku, kdy dojíždí ekocentrum do škol. Žáci byli vybráni pro rozhovor technikou popsanou výše a s tazateli šli do vedlejší místnosti. Pro vedení rozhovoru byla většinou poskytnuta třída nebo kabinet, kde se dalo posadit na gauč nebo na koberec. Tazatelé se snažili poskytnout dotazovaným žákům klidné prostředí. Rozhovory se nahrávaly na diktafon. Před každým rozhovorem si tazatelé poznamenali křestní jména a věk.

Pozorování probíhalo ve školní učebně, tělocvičně nebo na zahradě - tam, kde právě probíhal program. Jelikož pozorování bylo nezúčastněné, pozorovatelé se posadili někam do ústraní, aby nenarušovali dynamiku programu. Výsledky pozorování si zapisovali k pořízeným rozhovorům.

Vyplňování dotazníků probíhalo na začátku programu a po skončení programu. Zároveň se sbírala data od kontrolní skupiny, která neprošla programem na začátku a na konci školního roku.

Dotazník zadávalo třídě Ekocentrum, když bylo na jejich zahajovacím a ukončovacím programu ve školním roce 2010/2011. Lektoři Ekocentra instruovali všechny žáky stejně:

- Aby vyplňovali dotazník podle pravdy.

- Aby neopisovali, protože potřebujeme znát jejich názory.

Na dotazník dostali žáci maximálně 30 minut, což se ukázalo jako dostatečné. $\checkmark$ průběhu vyplňování testu se ve třídě udržoval klid. 
O sběr dat kontrolní skupiny byla požádána po předchozí domluvě paní učitelka, která realizovala program $v$ dané tř́dě. Instrukce jí byly vysvětleny stejně, aby byly zajištěny stejné podmínky. Sebraná data poté poslala evaluátorưm.

Přepisy rozhovorů se analyzovaly pomocí principů zakotvené teorie. Z přepsaných dat byly nejprve vyčleněny významové jednotky, které byly kódovány metodou otevřeného kódování. Procesem postupného zobecňování konceptů vzniklo schéma, obsahující jednu centrální kategorii a několik vedlejších (Hendl, 2008).

Dotazníky byly spárovány a označeny písmenem a číslem, aby je evaluátoři dále mohli rozeznat. Následně byly dotazníky bodově ohodnoceny a zpracovány. V první části testu respondenti kř́žkovali na bodové škále jedna až čtyři, ve druhé získávali body za správně identifikované př́klady špatného chování. Na tento typ dat byl využit t-test a byla vypočítávána velikost efektu (size effect). Data testu byla chápána jako intervalová. Pro všechny výpočty statistické významnosti byla hladina významnosti stanovena na a = 0,05.

\section{Zjištění}

\section{Kvantitativní část}

První část testu měřila míru, se kterou jsou děti procházející programem přesvědčeny o zvládnutí jednotlivých akčních kompetencí. Druhá pak ověřovala samotné akční kompetence, zde chápané jako schopnost identifikovat environmentálně neodpovědné chování a nahradit ho odpovědnou variantou.

Tabulka 4. Výsledky: experimentální skupina

\section{Test přesvědčení o zvládnutí akčních kompetencí}

\begin{tabular}{|l|l|l|l|l|l|l|}
\hline & $\mathrm{N}$ & Průměr & SD & $\mathrm{t}$ & $\mathrm{P}$ & ES \\
\cline { 1 - 6 } Pretest & \multirow{2}{*}{134} & 21,56 & 4,62 & \multirow{2}{*}{4,6732} & 0,0001 & 0,571 \\
\cline { 3 - 4 } & & 23,4 & 3,56 & & & \\
\hline
\end{tabular}

Test akčních kompetencí

\begin{tabular}{|l|l|l|l|l|l|l|}
\hline & $\mathrm{N}$ & Průměr & $\mathrm{SD}$ & $\mathrm{t}$ & $\mathrm{P}$ & $\mathrm{ES}$ \\
\hline Pretest & \multirow{2}{*}{134} & 2,36 & 0,92 & \multirow{2}{*}{2,8828} & 0,0046 & 0,29857 \\
\cline { 1 - 6 } & & 2,65 & 1,02 & & & \\
\hline
\end{tabular}

Tabulka číslo 4 vypovídá o tom, že program ovlivňuje měřené proměnné. Dosažená velikost efektu ukazuje, že program měl vysoký vliv na přesvědčení o zvládnutí akčních kompetencí a střední na samotné akční kompetence žáků.

Stejné měření proběhlo i v rámci kontrolní skupiny. 
Tabulka 5. Výsledky: kontrolní skupina

Test: přesvědčení o zvládnutí akčních kompetencí

\begin{tabular}{|l|l|l|l|l|l|l|}
\hline & N & Průměr & SD & T & P & ES \\
\hline Pretest & \multirow{2}{*}{96} & 21,82 & 3,44 & \multirow{2}{*}{1,4601} & 0,1476 & 0 \\
\cline { 3 - 4 } Posttest & & 21,26 & 3,97 & & & \multirow{2}{*}{} \\
\cline { 3 - 6 } & & & & & &
\end{tabular}

Test akčních kompetencí

\begin{tabular}{|l|l|l|l|l|l|l|}
\hline & N & Průměr & SD & T & P & ES \\
\hline Pretest & \multirow{2}{*}{96} & 2,41 & 1,03 & \multirow{2}{*}{0,0971} & 0,9229 & \multirow{2}{*}{0} \\
\cline { 1 - 3 } & \multirow{2nyyyy}{*}{ Posttest } & 2,4 & 0,99 & & & \\
\hline
\end{tabular}

Tabulka číslo 5 vypovídá o tom, že rozdíly $v$ kontrolní skupině nejsou statisticky významné. $V$ průběhu roku tedy $v$ kontrolní skupině nedošlo ke změnám na měřených proměnných.

Protože metoda výběru kontrolní skupiny nebyla založená na náhodném výběru, bylo nutné ověřit, zda mezi skupinami nebyly rozdíly již před zahájením programu.

Tabulka 6. Srovnání pretestů experimentální a kontrolní skupina

\section{Test přesvědčení o zvládnutí akčních kompetencí}

\begin{tabular}{|l|l|l|l|l|l|}
\hline & N & Průměr & SD & T & P \\
\hline Pretest: experimentální skupina & 134 & 21,56 & 4,62 & \multirow{2}{*}{0,4718} & 0,6375 \\
\hline Pretest: kontrolní skupina & 96 & 21,82 & 3,44 & & \\
\hline
\end{tabular}

Test akčních kompetencí

\begin{tabular}{|l|l|l|l|l|l|}
\hline & N & Průměr & SD & T & P \\
\hline Pretest: experimentální skupina & 134 & 2,36 & 0,92 & \multirow{2}{*}{0,3709} & \multirow{2}{*}{0,7111} \\
\hline Pretest: kontrolní skupina & 96 & 2,41 & 1,03 & & \\
\hline
\end{tabular}

Tabulka číslo 6 vyhodnocuje rozdíly v pretestech experimentální a kontrolní skupiny. Z výsledků vyplývá, že ze statistického hlediska byly obě skupiny na počátku programu srovnatelné. 
Tabulka 7. Srovnání posttestů experimentální a kontrolní skupiny

\begin{tabular}{|c|c|c|c|c|c|}
\hline & $\mathrm{N}$ & Průměr & SD & $\mathrm{T}$ & $P$ \\
\hline Posttest: experimentální skupina & 134 & 23,4 & 3,56 & \multirow{2}{*}{4,2712} & \multirow{2}{*}{0,0001} \\
\hline Posttest: kontrolní skupina & 96 & 21,26 & 3,97 & & \\
\hline \multicolumn{6}{|l|}{ Test akčních kompetencí } \\
\hline & $\mathrm{N}$ & Průměr & SD & $\mathrm{t}$ & $P$ \\
\hline Posttest: experimentální skupina & 134 & 2,65 & 1,02 & \multirow{2}{*}{1,881} & \multirow{2}{*}{0,0613} \\
\hline Posttest: kontrolní skupina & 96 & 2,4 & 0,99 & & \\
\hline
\end{tabular}

Stejné porovnávání bylo provedeno také u posttestu. Bylo naměřeno, že rozdíl u posttestů je statisticky významný, ku prospěchu experimentální skupiny. To potvrzuje závěr o vlivu programu na měřené proměnné.

V poslední části byly vyhodnoceny genderové aspekty programu. Předpokladem bylo, že program působí srovnatelně na chlapce i na dívky.

Tabulka 8. Srovnání: dívky experimentální skupiny

\section{Test přesvědčení o zvládnutí akčních kompetencí}

\begin{tabular}{|l|l|l|l|l|l|l|}
\hline & N & Průměr & SD & T & P & ES \\
\hline Pretest dívky & \multirow{2}{*}{68} & 21,04 & 5,24 & \multirow{2}{*}{3,9807} & 0,0002 & \multirow{2}{*}{0,485} \\
\cline { 3 - 7 } Posttest dívky & & 23,51 & 3,44 & & & \\
\hline
\end{tabular}

Test akčních kompetencí

\begin{tabular}{|l|l|l|l|l|l|l|}
\hline & N & Průměr & SD & T & P & ES \\
\hline \multirow{2}{*}{ Pretest dívky } & \multirow{2}{*}{68} & 2,37 & 0,81 & \multirow{2}{*}{3,2761} & 0,0017 & 0,439 \\
\cline { 3 - 4 } Posttest dívky & & 2,75 & 0,92 & & & \\
\hline
\end{tabular}

Pro zjištění možných rozdílů mezi dívkami a chlapci experimentální skupiny byl proveden párový t-test a test velikosti efektu. Tabulka číslo 8 vypovídá o posunu sledovaného jevu u dívek a tabulka číslo 9 o posunu u chlapců. 
Tabulka 9. Srovnání: chlapci experimentální skupiny

\section{Test přesvědčení o zvládnutí akčních kompetencí}

\begin{tabular}{|l|l|l|l|l|l|l|}
\hline & N & Průměr & SD & T & P & ES \\
\hline Pretest chlapci & \multirow{2}{*}{61} & 22,11 & 3,78 & \multirow{2}{*}{2,6418} & 0,0105 & 0,324 \\
\cline { 3 - 4 } Posttest chlapci & & 23,34 & 3,82 & & & \\
\hline
\end{tabular}

Test akčních kompetencí

\begin{tabular}{|c|c|c|c|c|c|c|}
\hline & $N$ & Průměr & SD & $T$ & $P$ & ES \\
\hline Pretest chlapci & \multirow{2}{*}{61} & 2,38 & 1,05 & \multirow{2}{*}{0,7532} & \multirow{2}{*}{0,4542} & \multirow{2}{*}{0,38} \\
\hline Posttest chlapci & & 2,51 & 1,12 & & & \\
\hline
\end{tabular}

$V$ testu velikosti efektu bylo naměřeno, že dívky byly oproti chlapcům $v$ bodovém zisku nepatrně lepší, rozdíl je ovšem zanedbatelný. Naměřené hodnoty velikosti efektu u dívek a chlapců jsou zhruba srovnatelné.

Tabulka 10. Srovnání pretestů: dívky a chlapci experimentální skupiny

\section{Test přesvědčení o zvládnutí akčních kompetencí}

\begin{tabular}{|l|l|l|l|l|l|}
\hline & N & Průměr & SD & t & P \\
\cline { 1 - 4 } Pretest dívky & 68 & 21,04 & 5,24 & \multirow{2}{*}{1,3179} & \multirow{2}{*}{0,1899} \\
\cline { 1 - 4 } Pretest chlapci & 61 & 22,11 & 3,78 & & \\
\cline { 1 - 4 }
\end{tabular}

Test akčních kompetencí

\begin{tabular}{|l|l|l|l|l|l|}
\hline & N & Průměr & SD & t & P \\
\hline Pretest dívky & 68 & 2,37 & 0,81 & \multirow{2}{*}{0,0573} & \multirow{2}{*}{0,9544} \\
\hline Pretest chlapci & 61 & 2,38 & 1,05 & & \\
\hline
\end{tabular}

Tabulka 11. Srovnání posttestů: dívky a chlapci experimentální skupiny

\section{Test přesvědčení o zvládnutí akčních kompetencí}

\begin{tabular}{|c|c|c|c|c|c|}
\hline & $\mathrm{N}$ & Průměr & SD & $\mathrm{t}$ & $P$ \\
\hline Posttest dívky & 68 & 23,51 & 3,44 & \multirow{2}{*}{0,2668} & \multirow{2}{*}{0,7901} \\
\hline Posttest chlapci & 61 & 23,34 & 3,82 & & \\
\hline \multicolumn{6}{|c|}{ Test akčních kompetencí } \\
\hline & $\mathrm{N}$ & Průměr & SD & $\mathrm{t}$ & $P$ \\
\hline Posttest dívky & 68 & 2,75 & 0,92 & \multirow{2}{*}{1,345} & \multirow{2}{*}{0,181} \\
\hline Posttest chlapci & 61 & 2,51 & 1,12 & & \\
\hline
\end{tabular}


Dále byl proveden nepárový t-test zvlášt́ u pretestů (viz tabulka číslo 10) a posttestů (viz tabulka číslo 11) dívek a chlapců experimentální skupiny. Tyto testy měly ověřit naměřené hodnoty zvlášt' u dívek a chlapců. U pretestů i posttestů nebyl naměřen statistický rozdíl. Lze usuzovat, že program je genderově vyvážený, a není tak atraktivnější pro jedno z obou pohlaví.

\section{Kvalitativní část}

Pro analýzu interpretace programu účastníky bylo na základě analýzy dat vytvořeno schéma obsahující jednu centrální a několik vedlejších kategorií.

\section{Obrázek 1. Interpretace programu účastníky}

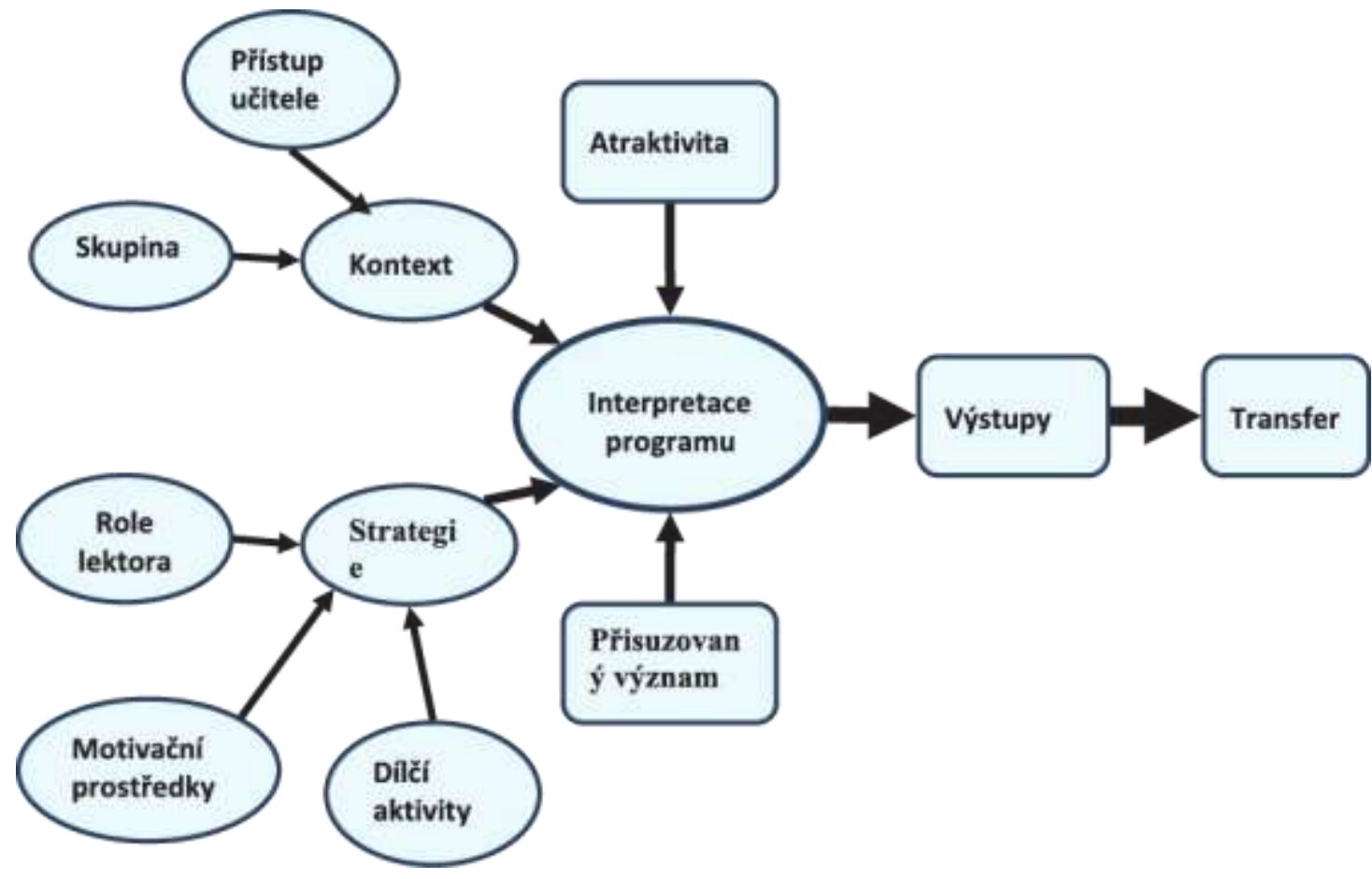

Centrální kategorií se stala Interpretace programu. Ta se skládá ze dvou dimenzí: hodnocení atraktivity programu a přisuzování významu programu. Účastníci v naprosté většině hodnotili program velmi pozitivně. Ocenili zejména hravou formu programu:

"Baví nás to, protože děláme taky chvíli něco jinýho než jenom učení, ale tim se učíme, hrajeme si a zároveň se učíme, kdybychom se takhle učili všechno, tak by nás to bavilo mnohem víc, jo, je to taková poučná hra."

Program pro ně znamenal jednak zábavu, jednak jim zprostředkoval konkrétní znalosti, posílil fungování jejich skupiny, rozvinul komunikační dovednosti a ovlivnil jejich proenvironmentální chování:

"Začali jsme spolupracovat $v$ týmech, dř́v jsme byli třeba kamarádi po dvou po třech a tak trochu odtržený od ostatních. A ted'jsme jakoby celá třída jeden tým."

"Třeba dřív mě príroda moc nezajímala a tedka se těším na každou hodinu, kdy máme zemi Turo."

Hodnocení dílčích aktivit programu je obsahem kategorie Strategie. Děti zde hodnotí práci lektorů, motivační rámec či jednotlivé aktivity. 
Účastníci byli s většinou aktivit spokojeni. Zejména oceňovali ty, ve kterých dostali možnost zkusit jinou roli, než mají obvykle ve škole, dále pak pohybové aktivity:

"Mě nejvíc bavily odpady, jak sme museli za odpad dělat třeba dřepy."

"To bylo dobrý, jak sme šli do toho lesa a psali, který stromy ubývaj."

"Mně se na tý dnešní (aktivitě) líbilo to sázení, že sme byli zapojení aktivně. Ne jen pořád sedět u stolu a psát, že sme mohli zalejvat a chodit a zapisovat"; "hejbali sme se u toho."

"Prostě jsme si tam vyzkoušeli život těch dospělejch. Bylo to takový zajímavý, vcítil ses do role někoho jinýho."

Pokud účastníci některou aktivitu hodnotili negativně, bylo to z důvodu její př́lišné náročnosti pro skupinu:

"ta hra v září na rodiny, no ale skoro nic sme ve hře nestíhali", "Pro naší skupinku bylo těžký kreslit ty postavy, a psali sme do toho, co spotřebuje a jak to vylepšit".

Velmi dobře hodnocenou strategií byl také motivační rámec. Všechny třídy (s výjimkou jedné, která nepracovala s komiksem) si pamatovaly všechny díly komiksu. Dobře hodnocena byla jeho zábavnost, propracovanost i estetické provedení:

"Bylo to takový srandovní, takový ironický. Jak oni to nechápali, a museli jim to vysvětlit takový to nechápání."

"Líbí se mi, že má každej ten tur nějaký jméno."

"Ty obrázky jsou hrozně hezký."

Stejný úspěch mělo vymýšlení mapy země Turo. Děti bavilo vymýšlení inovací, ale i vzájemné porovnávání svých map na internetu. Důležitý byl i pocit autonomie při jejich vytváření:

"No to stavění mapy je hezký, když se podíváte na internet, tak tam vidíte ty ostatní, co tam mají postavenýho."

„Mně se líbí, že když stavíme, že si navrhneme, kam by ta stavba byla nejlepš̌i."

"Mě zase baví to, že třeba musíme rozhodovat o těch kartičkách, co na ně nakreslíme, anebo si to koupit a pak to tam nalepit, a to mě baví o tom rozhodovat."

Negativní hodnocení motivačního rámce se objevilo jen $v$ jedné skupině. Část tř́́dy byla přesvědčená o tom, že země Turo opravdu existuje, zatímco druhá tomu nevěrila. Tato situace vedla k jistému rozčarování.

Pozitivně byla vnímána také role lektorů z ekocentra:

"Mně se líbilo, jak za náma přijeli lektoři a byli v tom zastupitelstvu, vždycky se mi líbí, jak za náma príijedou lektoři."

Kategorie Kontext zahrnovala skupinu spolužáků, rodinu, práci učitele s programem a jeho př́stup. Kontext programu $v$ některých ohledech usnadňoval pozici, $v$ jiných naopak ztěžoval. Program byl závislý na učiteli, který vedl většinu aktivit. $V$ jedné skupině se učitel rozhodl vynechat práci s komiksem, čímž oslabil motivační rámec programu.

Důležitým faktorem byla schopnost skupiny spolupracovat. Pokud tř́da nebyla dosud připravená na týmovou práci, vznikaly $v$ průběhu programu rozbroje typické pro fázi 
bouření (viz...). Spolu s tím rostlo vnímání aktivit vyžadujících kooperaci jako náročné a ne zcela př́ijemné:

"Mně se nelíbilo, je hrozně těžký dohodnout se v těch skupinách, dva lidi mají jiný názor a jaký názor si vybrat, že jo, pak se začnou hádat a ty hádky to se mi tam nelíbí. To je prostě hrozný".

"Pracovní listy, tak to nikdy nevyplníme a vždycky se pohádáme."

„....mně se třeba nelíbí, že $v$ tý skupině někdo moc nepracuje, zrovna třeba ten úkol, někdo se má třeba rozhodnout a pak si za tím stojí, i když třeba prostě nepracoval. Že prostě nepracuje a pak si něco vymyslí, že to chce"

V jedné třídě bylo zaznamenáno, že vytvořené skupiny nefungovaly a odmítly spolupracovat. V průběhu programu ale docházelo k posunu ve vývoji skupin, což někteří respondenti pozitivně reflektovali. Z více výpovědí vyšlo najevo, že se žáci spolu naučí v průběhu programu spolupracovat, přestože program cíleně jejich kooperativní dovednosti nerozvíjel.

Je pravděpodobné, že úspěch programu ovlivňovalo i to, že žáci na školách pravděpodobně neměli dost zkušeností s aktivními formami výuky. Vzdělávací hry proto možná hodnotili pozitivněji, než kdyby tyto metody pro ně byly běžné.

Interpretaci programu dále ovlivňovala rodina. Žáci bohužel reflektovali spíše nezájem rodičů o program:

„....já sem do toho třeba rodiče nezapojil, protože je to nebaví a nezajímá. Třeba dneska ráno sem jim oznámil, že za náma přijedou dneska lektoři okolo turu a oni nezájem. Spíš třeba někdy ř́kej, že je škola od toho abychom se tu učili."

Poslední kategorií, byly Výstupy programu, kam patřily výpovědi týkající se učení, transferu a prínosů programu. Respondenti zde přecházeli od hodnocení významu programu k popisu reálných změn, které připisovali programu. Podle některých vyjádření program vedl ke změně jejich akčních teorií (Johnson \& Johnson 2006), tedy modifikoval jejich přesvědčení o optimální cestě k dosažení určitého cíle. Změny se týkaly především zdravého životního stylu a odpovědného nakládání s přírodními zdroji:

„...třeba sportem ku zdraví, že jsme pochopili, že si nemůžeš dát prášek a budeš mít svaly, ale že musíš cvičit"

"...třeba když je topení, tak se ten závěs nesmí dát přes to"

„...ovoce a zeleninu je lepší dát do skleníku, aby se u sadu nedával chemický postřik"

V jiných případech program ovlivnil postoje účastníků a posílil jejich odhodlání k proenvironmentálnímu chování:

„...že je jako lepší jít pěšky než jet autem, že to bysme měli trošku změnit"

"Já sem třeba dřív netřídila odpad, sice to doma máme rozdělený, ale já jsem to začala až tedka třídit, protože mě to opravdu chytlo."

Další respondenti využili získané znalosti k přesvědčování ostatních k proenvironmentálnímu chování:

"...táta dává trávu na kompost, já sem mu to vysvětlil, on to nedělal"

„....napsali jsme dopisy paní ředitelce o šetření energií." 


\section{Hlavní zjištění}

- Účastníci program hodnotí převážně pozitivně.

- Většina účastníků pozitivně hodnotí motivační rámec programu a připisuje mu velký význam pro vlastní vtažení do programu.

- Účastníci uvádí, že program rozšířil jejich znalosti, ovlivnil postoje a vedl je ke změnám v chování.

- Program je vnímán a působí stejně na chlapce i na dívky.

- Program dále ovlivňoval vztahy ve skupině, současně byl těmito vztahy ovlivňován.

- Program posílil přesvědčení dětí o zvládnutí vybraných akčních kompetencí.

- Program rozvinul schopnost dětí identifikovat odpovědné a neodpovědné environmentální chování.

\section{Diskuse}

Evaluace ukázala, že dlouhodobé komplexně zpracované programy mohou přinést předpokládaný efekt. Výsledky je současně třeba hodnotit ve světle limitů provedené evaluace. Při dotazníkovém šetření nelze vyloučit stylizace respondentů do sociálně žádoucích odpovědí. Při identifikaci správného a nesprávného chování mohli být znevýhodněni žáci, kteří mají problémy se čtením. Protože kontrolní skupina nebyla vybrána náhodně, ale metodou párování, nelze vyloučit, že zcela neodpovídala běžné populaci. Přestože kvaziexperimenty,pro které je takový design typický, jsou považovány za akceptovatelné evaluační plány, je třeba upozornit na jejich limity. Nelze např́klad vyloučit, že učitelé se žákům v experimentálních třídách věnují ve srovnání s kontrolními více i nad rámec programu (Mertens, 2010).

Ohniskové skupiny, které byly voleny jako hlavní metoda pro sběr kvalitativních dat, sice umožnily žákům na sebe reagovat, na druhou stranu mohly blokovat žáky v otevřenějších a kontroverznějších výpovědích o programech. Evaluace dále neměřila celou řadu dalších proměnných, jejichž vyhodnocení by mohlo být pro porozumění fungování programu důležité - např. samotné deklarované proenvironmentální chování dětí či proenvironmentální postoje.

Přestože program funguje velmi dobře, je možné zaznamenat i některé jeho problematické body. Program je značně variabilní, což znamená, že učitelé si v rámci jednotlivých tematických bloků mohou vybírat aktivity do jisté míry podle svého uvážení. To může vést k tomu, že sice učitelé optimalizují program pro potřeby svých žáků, ale otevírá to i rizika. Nelze vyloučit, že při větší volnosti by učitelé mohli rozvolnit kázeň natolik, že by program jako celek přestal být evaluovatelný. Větší neuvážené změny také mohou ohrozit fungování programu.

Tento problém se objevil na jedné ze zkoumaných škol, ve které učitel vyřadil práci s motivačním rámcem. Takové rozhodnutí může program podstatně ovlivnit a změnit jeho vyznění.

Program obsahuje řadu kooperativních aktivit, a je tak závislý na fungování skupiny. Současně nijak cíleně neučí žáky spolupracovat. Děti jsou tak "hozeny do hluboké vody". Pokud jsou vztahy ve skupině na dobré úrovni, je vše v pořádku. Pokud tomu tak není, prochází třída procesem vývoje vztahů ve skupině více či méně živelně, což může podvázat účinnost jednotlivých aktivit. 
Program probírá široké spektrum témat. Může se tak stát, že bude účastník zahlcen, $z$ jednotlivých témat si odnese méně znalostí, než kdyby se některá témata probírala více do hloubky. Prípadná evaluace by se proto mohla zaměřovat i na analýzu nově získaných znalostí.

Z programu není patrné, zda jsou aktivity $v$ jednotlivém měsíci uskupeny podle nějakého modelu učení. $V$ několika tématech se objevuje tř́fázový konstruktivistický model učení EUR: evokace, uvědomění a reflexe. Je možné, že by větší využití vhodných modelů pomohlo program ještě více integrovat. Za zvážení by rovněž stálo využití modelu 4MAT (McCarthy, 2011), který umožňuje dobře propojit fáze učitelem řízené výuky se samostatným projektem, ve kterém žáci aplikují osvojené znalosti a dovednosti.

Program na druhé straně uplatňuje řadu velmi účinných strategií. Za velmi osvědčenou strategii lze považovat $v$ programu použitý motivační rámec. Zdá se, že skutečně pomohl „zaháčkovat" a „ponořit” účastníky do programu. Některé výpovědi dětí naznačují, že úkoly spojené s motivačním rámcem dobře nastavovaly hranici mezi př́liš náročnými a přiliš jednoduchými výzvami. Děti si ve většině případů uvědomovaly, že motivační rámec je pouze "jako", tj. pohybovaly se na vhodné úrovni mezi př́lišným „ponořením" a "odstupem". V případě skupiny, kde tato hranice byla překročena ve prospěch ponoření, došlo ke kontroverzím a dílčím zklamáním. Ve většině skupin ale motivační rámec mohl děti zaujmout, pobavit a motivovat k soustředění se na úkol. V důsledku se mohl projevovat stav "flow" (Shernoff et al., 2003).

Program poměrně často zařazuje aplikační aktivity. Aplikace se odehrávaly bud' ve virtuálním prostoru mapy země TURO, nebo ve školním prostředí (např. návrh úsporných opatření). Propojení programu s virtuálním světem vzdáleně připomíná prostředky, používané pro posilování v programech výchovy o Zemi (Matre, 1999). I v nich jsou děti symbolicky odměňovány za splnění určitého úkolu (například získáním klíče či vyznamenání). Současně i v nich dochází k postupnému přesunu ze symbolického světa do reálného a k zařazování aplikačních úkolů mimo „herní svět”.

Zařazování aplikačních úkolů, ve kterých žáci řeší reálné problémy ve svém okolí, koresponduje scelou řadou doporučení. Standardy Severoamerické asociace pro environmentální výchovu (NAAEE) například doporučují, aby pracovní podklady pro výuku environmentální výchovy kladly dưraz na rozvíjení dovedností řešení konkrétních problémů a konfliktů. Programy by měly být akční a propojovat výuku s vlastním životem (NAAEE, 2004). Obdobně Eilat a Trop (2011) doporučují, aby výchova k udržitelnému rozvoji nezahrnovala pouze "akademické učení", ale aby umožňovala dětem zapojovat emoce, věnovat se tématům prưřezově napříč předměty a $z$ více perspektiv.

Přestože program prokázal svoji funkčnost, přinesly by další evaluační šetření nové informace. Kromě již zmíněných by bylo zajímavé zaměřit se na vzájemné pưsobení programu a skupiny. Důležitým výzkumným tématem je také samotný metodický rámec uplatňovaný v integrované tematické výuce. Další výzkumy by mohly přinést více poznatků o předpokladech jeho úspěšné implementace i o vlivu, jaký má na efektivitu programu.

\section{Literatura}

- Činčera, J., \& Macháčková, P. (2009). Evaluace pobytového programu Podblanického ekocentra. Envigogika, 4(3), 10-14712. Retrieved from http://www.envigogika.cuni.cz/index.php/Envigogika/article/view/42 http://dx.doi.org/10.14712/18023061.42

- Daňková, L. (2010). Výroční zpráva 2009. Praha: SSEV Pavučina. . 
- Darner (Rebeka), (2009). Self-Determination Theory as a Guide to Fostering Environmental Education. The Journal of Environmental Education, 40(2), 39-49. http://dx.doi.org/10.14712/18023061.2013.8.3

- Eliat, E., \& Trop, T. . ESD Pedagogy: A Guide for the Perplexed. Journal of Environmental Education, 2011(1), 43-64.

- Hendl, J. (2008). Kvalitativní výzkum. Praha: Portál.

- Daniš, P. (2014). A new definition of environmental literacy and a proposal for its international assessment. Envigogika, 8(3), http://dx.doi.org/10.14712/18023061.385

10-14712.

- Horká, H., Činčera, J., \& Koštálová, H. (2009) Pedagogická a psychologická východiska ekologické / environmentální výchovy. Škola pro život II. Jak na ekologickou / environmentální výchovu po zavedení Rámcových vzdělávacích programů. Praha: Sdružení středisek ekologické výchovy Pavučina. In L. Daňková, J. Kulich, \& B. Toušková (Eds.), Škola pro život II. Jak na ekologickou / environmentální výchovu po zavedení Rámcových vzdělávacích programů (pp. 51-62). : Sdružení středisek ekologické výchovy Pavučina.

- Hornová, K. (2007). Evaluace výukového programu. Envigogika, 2(3), 10-14712. Retrieved from $\quad$ http://www.envigogika.cuni.cz/index.php/Envigogika/article/view/22 http://dx.doi.org/10.14712/18023061.22

- Hořavová, K., \& Klápště, P. (2006). Symbolický rámec podle 3. B. Praha: Junák - svaz skautů a skautek ČR. .

- Chráska, M. (2007). Metody pedagogického výzkumu. Praha: Grada.

- Johnson, D. W., \& Johnson, F. P. (2006). Joining Together. Group Theory and Group Skills. Boston: Pearson.

- Kovalik, S. J., \& Olsen, K. D. (1994). Kid's eye view of science. A Teacher's Handbook for Implementing an Integrated Thematic Approach to Teaching Science, K-6. Kent: Center for the Future of Public Education. .

- Martin, D. (2003). Research in Earth Education. Zeitschrift für Erlebnispädagogik, 23(5/6), 32-47.

- Van_Matre, S. (1999). Earth Education .. a new beginning. Greenville: The Institute for Earth Education. .

- Matre, v. (Steve), , \& Johnson, B. (1998). Earthkeepers. Greenville: The Institut for Earth Education.

- McCARTHY, B. . About Learning. Offical Site of McCarthy's 4MAT System. . Retrieved from http://www.aboutlearning.com/

- Mertens, D. M. (2005). Research and evaluation in education and psychology: Integrating diversity with quantitative, qualitative, and mixed methods. Thousand Oaks, Calif.: Sage Publications.

- Musser Lynn M, , \& Malkus Amy J, (1994). The Children's Attitudes Toward the Environment Scale. Journal of Environmental Education, 25(3), 22-26.

- NAAEE Environmental Education Materials: Guidelines for Excellence (2004). Washington: NAAEE.

- Patton, M. Q. (2002). Qualitative Research and Evaluation Methods. Thousand Oaks: Sage.

- Water, R. (2011). Water Wise - Water Conservation and Education Campaign by Rand Water. : Rand Water. Retrieved from http://www.waterwise.co.za/site/home.html

- Rickinson, M. (2001). Learners and Learning in Environmental Education: a critical review of the evidence. Environmental Education Research, 7(3), 207-320. 
- Shernoff, D., Csikszentmihalyi, M., Schneider, B., \& Shernoff, E. S. (2003). Student engagement in high school classrooms from the perspective of flow theory. Psychology Quarterly, 18(2),

- Škvaříček, R., Šed'ová, K., (2007). Kvalitativní výzkum v pedagogických vědách. Praha: Portál.

- Zelezny, L. C. (1999). Educational Interventions That Improve Environmental Behaviors: A Meta-Analysis. The Journal of Environmental Education, 31(1), 5-14. Retrieved from http://www.tandfonline.com/doi/abs/10.1080/00958969909598627 http://dx.doi.org/10.1080/00958969909598627 
Časopis Envigogika vydává Centrum pro otázky životního prostředí UK. Vývoj časopisu je podpořen projektem OP VK Mezioborová sít udržitelného rozvoje.

Více najdete na internetových stránkách projektu mosur.czp.cuni.cz
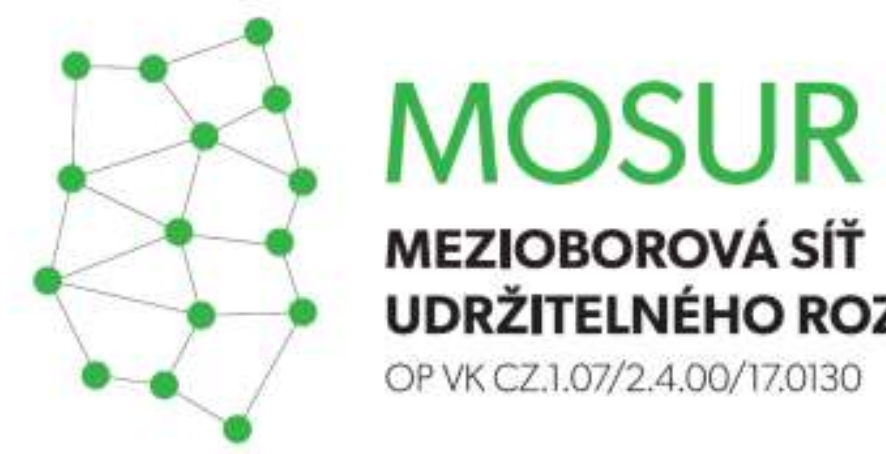

\section{MEZIOBOROVÁ SÍT} UDRŽITELNÉHO ROZVOJE

OP VK CZ.1.07/2.4.00/17.0130
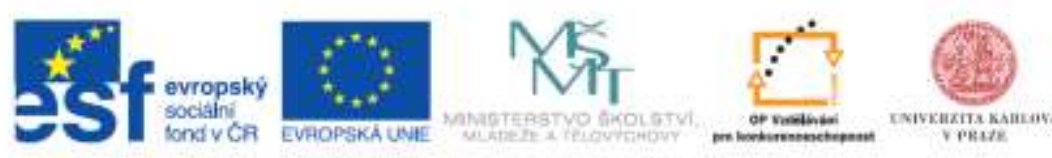

INVESTICE DO ROZVOJE VZDELAVANI 